International Journal of Biology, Pharmacy and Allied Seiences (IJBPAS) 'A Bridge Between Caboratory and QRader'

\author{
WwW.ibpas.com
}

\title{
WORKPLACE HARESSMENT AND PSYCHOGICALWELL BEING OF WORKING WOMEN
}

\section{AMBREEN MASOOD ${ }^{1}$, MAHGAUL KHAJJAK ${ }^{2}$, KANWAL ASHFAQ ${ }^{3}$, SEEMAB ABID ${ }^{4 *}$ AND NOREEN QUDOOS ${ }^{5}$}

1: Assistant Professor Social Work Department, SBK Women University, Quetta, Pakistan

2: Lecturer Social Work Department SBK Women University, Quetta, Pakistan

3: Lecturer, Social Work Department, SBK Women University, Quetta, Pakistan

4: Lecturer, Sociology Department, SBK Women University, Quetta, Pakistan

5: Research Officer Sociology Department SBK Women University, Quetta, Pakistan

*Corresponding Author: ABID S: E Mail: seemababid@gmail.com

Received $30^{\text {th }}$ Jan. 2020; Revised $2^{\text {nd }}$ March 2020; Accepted $7^{\text {th }}$ April 2020; Available online $1^{\text {st }}$ Sept. 2020 https://doi.org/10.31032/IJBPAS/2020/9.9.5199

\begin{abstract}
Harassment has been a tragedy of the workplace since women first began to work outside the home. Particularly in developing countries like Pakistan where working women confront degrading, frightening, and sometimes physically violent behaviors frequently extends over a considerable period of time; and can bring about significant occupation related, psychological, and health- related outcomes. This article is going to provide a brief review of the prevalence of workplace harassment, its effect on mental health and coping strategies to survive at work place and make work life functional as much as possible. The primary objective of the study is to explore the effect of visible and invisible harassment at workplace on mental health. The researcher selected 152 respondents from educational sector, banking sector and non-governmental organizations randomly. A quantitative research approach has been taken to fulfill the objectives of this research. And self-administrative questionnaire was used for data collection. The results revealed that visible and invisible harassment is affecting women and results in stress, physical and verbal aggression, and other job related issues that are making work environment more adverse for women to work.
\end{abstract}

Key words: Harassment, Degrading, Frightening, Physically violent, Aggression, Stress 


\section{INTRODUCTION}

Globalization with shifting patterns of life has changed the economic world today. Earning income has no longer remains the domain of men only. Women are taking part in economic activities and in this journey they are facing various hurdles (Naveed, Tharani \& Alanis, 2010).

Stereotyping, under representation, harassment and other serious issues are the obvious barriers that women came across in the way of their employment (Guney, Gohar, Akinci, \& Akinci, 2006). Harassment against women is as old as the very existence of women which restricts them to develop with their fullest potential and contribute their positive part in the development of the nation (Joshi \& Nachison, 1996). Workplace harassment includes all those acts that makes women to feel bad, uncomfortable and annoy them to work effectively interferes with work, made a condition of employment or creates an intimidating, hostile or offensive environment Women are affected by harassment irrespective of their age, marital status, physical appearance, background and professional status, family type, ethnicity and religion etc (Kamal, Hassan \& Khalil, 2002).

Patriarchal system of Pakistan in general and specifically of Baluchistan has limited the promotional opportunities for women. Females in Baluchistan are struggling hard for their progress and somehow achieved it as they are developing educationally and taking part in economic activities. Major Changings have occurred in layout of Pakistani economy but the cultural framework and expectations from women have not changed much. The circumstance has turned out to be more complicated for women with double demands of doing jobs where harassment is practiced as masculine social norm and keeping up respect of the family.

Harassment is also linked with negative psychological impacts for women such as anxiety, depression, isolation, lower selfesteem, tension, aggression , anger, hostility and nervousness along with negative psycho somatic outcomes like headaches, neck pain, nausea, high BP, insomnia etc (Bond, Kalaja, Markkanen, Cazeca, Daniel, Tsurikova, \& Punnett, 2007).

The major purpose of present research was to explore the relationship between work place harassment and its influence on psychological wellbeing of working women. The main focus was on the negative impacts on psychological wellbeing of women.

\section{Literature review}

Harassment is a confusing term and different people define harassment in a different way. There are contradictory concepts regarding harassment in different 
countries like Mobbing in France and Germany, Harassment in Finland, Bullying in Australia, Victimization, Psychological terror, Aggression and Emotional abuse at workplace in USA (Keashly \& Harvey, 2006) and anti-social workplace behavior (Einarsen, Hoel, Zapf, Cooper 2011 \& Saunder, Huynh \& Goodman, 2007). We can find workplace discrimination in Pakistani society on two grounds. At one hand the miss leading cultural values demands a sex segregated system in society where women should remain in homes and if they come out to join workplaces than men are not responsible for harassment that they face. On other hand so called modernism give men liberty that women are available for them who may want them (Zakaria, Ali \& Yousaf, 2016).

Harassment can take many forms depending on the situations; here researcher divided these in to following categories:

\section{Gazing and Eye Making}

One of the most interesting studying about gaze is conducted by Gervais, Vescio, \& Allen, (2011) titled as "When what you see is what you get" in which they associated gaze with objectification of women. They concluded that gaze is associated with cultural objectification of women thus when a man look at a women he look at sexual object which ultimately linked to the sexual harassment. The common trend of harassment experienced by every woman is of being gazed and stared at work place (Kaschak 1992). Feminist have identified this objectifying treatment as risk and harm for women mental health. Physical attributes undoubtedly creates unique experiences for women at workplace. Women's expectation of the portraying gaze from men causes increase shame and social physique anxiety (Calogero, 2004). Bartky in her book "Femininity and Domination: Studies in the Phenomenology of Oppression" has shared an experience of a young lady that in most of her interviews where interviewer were men, they stared at her physical appearance badly instead of taking interviews seriously. She felt uncomfortable, humiliated, performed badly and fails to get that job.

\section{Touching and blackmailing}

Studies have shown that harassment in terms of authority of harasser brings blackmailing for victim with inducement of granting any favor to the harasser failure to which bring negative consequence for the victim like demotion, workload etc. (Aloka 2009). A report on workplace harassment and violence (2004) revealed several touching blackmailing harassment cases. Almost every respondent reported touching and blackmailing as one of the respondent said that when she newly joined office and, in those days, her supervisor used to touch her and threatened her persistently to fire. 
She wanted to deal with it but she just got the job so remained silent. This is like helping others while helping sexual frustration.

\section{Friendship offers and undue favor}

Workplace friendships are often considered as a positive feature of organizational culture, but sometimes they cause discomfort for employees and productivity related issues in the organization specially in case of female workers. A qualitative study was conducted on such behaviors at workplace. The victim shared her experience of harassing by her boss; he started with her with friendship and share tea and lunch times with her. $\mathrm{He}$ was a, married man and uses to share his unhappy married life with her asking her his friend and ends up with her for asking sexual favors. She refuses and he stared teasing her and at last she has to quit her job (Kamal, Hassan \& Khalil 2002).

Unnecessary calls and visits of room (Hostile work environment)

Unwanted attention at workplace includes repetitive requests for dates, persistent messages or phone calls, and unwanted physical contact, unnecessary visits of room etc. Such unwanted attention is an indicator of a "hostile environment," (Wear \& Aultman 2005). Wesselmann \& Kelly (2010) conducted an experimental study on harassment. They introduced an interactive form of harassment by placing personal characteristics with phone calls, situation or context and explored that the form of harassment varies when a person is alone and when she is in gathering. The form of harassment in gathering is more embarrassing and effective to discourage the confidence of a person than harassment in a lonely situation. Owens, Rosner, \& Harmon (1995) found that most of the people received calls which possible are sexual invitations. Numerically he explored that almost $41 \%$ of the respondents received calls repeatedly having sexual content, threatening tone and sexual invitations.

\section{Picking and unfair treatment}

Women come across different difficulties and mental health risk due to be treated as commodity. It is a form of gender inequality faced by women creating hurdles in form of employment discrimination, sexual violence and lack of work accomplishment.

Harassment as Barrier in promotional opportunities

Feminist scholars say that the harassment and treating women as commodity by men involves the act of disregarding the personal and intellectual abilities and capabilities of a female; and reducing a woman's worth or role in society (LeMoncheck 1997).

Sexual Harassment and Gestures 
Similarly Sexual harassment involves sexual advances or conduct linked to an employment decision. Generally, it refers to a supervisor insisting upon sexual activities in return for promotions, other job benefits or continued employment decisions such as work assignments, salary, position transfers or promotions and the harasser's sexual advances or requests for favors (Chambers 2001).

Furthermore the phenomenon of sexual harassment is also related with gender stereotyping that is clearly discussed as a type of sexual discrimination in the work place that is annoying sexual advances or favor, and conduct that is directed toward a person because of gender says Linda (2007). Similarly the socio cultural explanations of sexual harassment focus on the patriarchal norms and stereotypes that give dominant status upon men. In this view, gender is a status characteristic that gives men authority to harass women (Blackstone, Houle \& Uggen 2014).

\section{Bullying}

Keeping in view the power element involve in threatening the female employees researchers have identify two ways that supervisors can uniquely exercise power the first one is; they have control over various work-related outcomes including positive performance evaluations, salary increases, and flexible work scheduling. Secondly they also have the ability to threaten the use of sanctions for example termination or demotion etc .Thus, the formal position power a supervisor holds may be used to threaten subordinates (Blackstone, Houle \& Uggen 2014). Furthermore Fitzgerald, Gelfand, \& Drasgow (1995) claimed that threatening women at workplace is very common which creates a hostile working environment and considered as insulting and degrading attitudes towards women that can be referred to as gender based harassment/discrimination.

\section{Psychological effects of Harassment at workplace}

Workplace harassment is characterized as a major work-related vulnerability that threatens psychological health of employees Scholars have worked extensively on effects of harassment and concluded that there are many different impacts of harassment on victims depending on the severity and seriousness of the problem like disappointment, stress aggression and many other (Gutek \& Koss, 1993).

\section{Workplace harassment and Stress}

Harrison \& Kanoff (2010) claimed that several mental health factors are positively associated with harassment, for example, stress, depression and anxiety. However, Vogt, Bruce Street \& Stafford (2007) explored that $2 \%$ working women 
negatively, $74 \%$ positively and $24 \%$ of working women remained neutrally coped with stress at workplace harassed environment. Smith (2008) quoted a story of a woman who claimed to be harassed at work place and reported to police under the act of "workers' safety and insurance". She told that she had been working as a data entry clerk in a store for nine years. During the period of her job, she had constantly tolerated the abusive behavior of colleagues. Initially, she was instructed to tolerate the behavior of her coworkers and manage to make good relationship with them the situation was becoming worst. She reported to the managers and her working hours were reduced. She reported to have severe headache, sleeping disorder and persistent stress. O'Reilly, S. (2008) mentioned a survey results that depression, anxiety and stress were the most common problems at workplace. In his study, stress, specifically, and mental health, generally, was associated with harassment and bullying at work place.

\section{Workplace harassment and aggression}

Similar to the harassment and stress association, several studies also explored that harassment caused to increase aggression factors among employees at workplace (e.g., Schat \& Kelloway, 2000). For example, Hershcovis (2006) in his doctoral dissertation of meta-analysis regarding harassment and aggression concluded that harassment and aggression are associated factors at workplace. $\mathrm{He}$ further explained that aggression by supervisor has stronger affect than coworkers and coworkers' aggression has greater effect than out-siders. Another interesting study by Lucero, Allen \& Middleton (2006) studied the behavior, motives and change in sexual harassment overtime. They explored that factors or attributes related to the harassers with qualitative coding while quantitative analysis. They concluded that harassers had previous aggression history which defines the association of harassment motives intrinsically. In other words, aggressive behavior increases the likelihood of sexual harassment behavior.

\section{Research Question}

How workplace harassment is affecting the psychological wellbeing of working women in Quetta City?

\section{Hypothesis}

Workplace harassment has negative psychological effects on working women.

Workplace harassment is related with negative psychological consequences for women such as anxiety, depression, lower self-esteem, tension, aggression anger, stress, hostility and nervousness along with negative psycho somatic outcomes like headaches, neck pain, nausea, high BP, insomnia etc. The major purpose of present research is to explore 
the relationship between work place harassment and its influence on psychological wellbeing of working women.

\section{Research Methodology}

The purpose of this research was to explore the psychological effects of workplace harassment on working women Quantitative research approach was adopted and survey method was selected for quantitative measurement of the phenomena. Data was collected from 152 respondents from those sectors in which female labor participation is higher which were Universities, banking and NGOs. Simple random sample has been used and research was carried out through survey method while data was collected by using self-administrative questionnaire. Therefore, researcher used the five point likert scale to find out the intensity and positive/negative responses of the respondents for self-administrated part of questionnaire (Visible and invisible harassment). DASS (Depression, Anxiety and Stress Scale) was used to measure the intensity of the psychological effects of harassment on respondents. The benefit of formulating structured questionnaire was that it helped the researcher to have the exact responses which further helped in testing hypothesis, answering research question and finally drawing conclusions from the responses.

\section{RESULTS}

Friendship offers has been considered one of the frequent methods of harassment, in present research, researcher have found the almost $66 \%$ of the respondents reported that they have been offered friendships in working places by varying frequency while only $34 \%$ of the respondents claimed that they have never encountered such sort of harassment.

It was reported that majority of the respondents $(70 \%)$ have never been touched at working place while very little number of respondents (4\%) claimed that they have encountered such sort of harassment. Interestingly, contrary to the previous researches, majority of the respondents i.e. $71 \%$ and $70 \%$ have never been harassed by black mailed and threatened respectively. Similarly, little number of the respondents i.e. $19 \%$ and $30.3 \%$ reported that they have faced unnecessary visits and calls from male colleagues respectively. The findings depicts that most of the respondents (45\%) faced unnecessary praising whereas same percentage of respondents $(45 \%)$ have never been scolded in front of colleagues. It was also found that very little percentage of respondents $(10 \%)$ reported that they have been demotivated at their work place directly but they had to face over load of work $(56 \%)$. 
Interestingly, most of the respondents $(59 \%)$ responded that they have never been posed threatening gestures; have never been bullied (63\%); have never been taunted with waggish jokes (66\%); have never been treated unfairly (59\%): have never been picked up from homes $(76 \%)$ and have never been seduced by sexual gestures (78\%). However a little percentage of respondents $(36 \%)$ reported that male colleagues obstacles in their promotional opportunities.

The results (Table 1, 2) showed that description of all the items of Buss-Perry Aggression Scale (1992) along with its sub scales explored by exploratory factor analysis. The description showed that majority of respondents reported do not have characteristics of physical aggression $($ Mean $=23.1, \mathrm{SD}=10.4)$ as percentages from items PA1 (41\%), PA2 (45\%), PA 7 (42\%), PA8 (45\%) and PA9 (50.7\%) affirmed it. Accumulatively, responses on verbal aggression $($ Mean $=16.17, \mathrm{SD}=$ 7.32) revealed almost no difference between its existence and non-existence among respondents that showed that cultural coercion on women. Females have been socialized in Baluchistan to be acquiesced to family values and submissive to patriarchic structure that resulted in the construction of subservient and reserved nature. Thus, as the table depicts, they reported least level of anger $($ Mean $=22.15$, $\mathrm{SD}=10.42)$ and hostility $($ Mean $=25.93$, $\mathrm{SD}=10.9$ ) as well. However, overall it can be inferred that they have suffering from worse mental condition because of the persistence tolerance of such harassment they have reported they encountered with at work place. 
Research Article

\begin{tabular}{|c|c|c|c|c|c|c|c|c|}
\hline \multicolumn{8}{|c|}{ Table 1: Description of visible harassment at work place } & \\
\hline & \multicolumn{2}{|c|}{ Items } & Never & Rarely & Often & SOT & MOT & \\
\hline & \multicolumn{2}{|c|}{ Gazing } & $31(20.4)$ & $30(19.7)$ & $39(25.7)$ & $32(21.1)$ & $20(13.2)$ & \\
\hline & \multicolumn{2}{|c|}{ Winking/nictitating } & 33 (21.7) & $32(21.1)$ & 27 (17.8) & $42(27.6)$ & $18(11.8)$ & \\
\hline & \multicolumn{2}{|c|}{ Friendship offers } & $51(33.6)$ & 28 (18.4) & $30(19.7)$ & $23(15.1)$ & 19 (12.5) & \\
\hline & \multicolumn{2}{|c|}{ Undue favors } & $80(52.6)$ & 27 (17.8) & $12(7.9)$ & $21(13.8)$ & $12(7.9)$ & \\
\hline & \multicolumn{2}{|c|}{ Touching } & $107(70.4)$ & 24 (15.8) & $9(5.9)$ & $06(3.9)$ & $6(3.9)$ & \\
\hline & \multirow{2}{*}{\multicolumn{2}{|c|}{$\begin{array}{l}\text { Black mailing } \\
\text { Unnecessary calls }\end{array}$}} & 108 (71.1) & $21(13.8)$ & $9(5.9)$ & 07 (4.6) & 7 (4.6) & \\
\hline & & & $64(42.1)$ & $26(17.1)$ & $16(10.5)$ & $29(19.1)$ & 17 (11.2) & \\
\hline & \multicolumn{2}{|c|}{ Unnecessary visits of room } & $70(46.1)$ & $29(19.1)$ & $24(15.8)$ & $18(11.8)$ & $11(7.2)$ & \\
\hline & \multicolumn{2}{|c|}{ Threatening behavior } & $107(70.4)$ & $23(15.1)$ & $7(4.6)$ & $8(5.3)$ & $7(4.6)$ & \\
\hline Sub Scales & Items & 1 & 2 & 3 & 4 & 5 & 6 & 7 \\
\hline \multicolumn{9}{|c|}{ Physical aggression } \\
\hline & PA1 & $62(40.8)$ & $30(19.7)$ & 19 (12.5) & $25(16.4)$ & $6(3.9)$ & $9(5.9)$ & $01(0.7)$ \\
\hline & PA 2 & 69 (45.4) & $38(25.0)$ & $16(10.5)$ & 19 (12.5) & $4(2.6)$ & $6(3.9)$ & - \\
\hline & PA 3 & $52(34.2)$ & $21(13.8)$ & 17 (11.2) & $23(15.1)$ & $15(9.9)$ & $10(6.6)$ & $14(9.2)$ \\
\hline & PA 4 & $56(36.8)$ & 28 (18.4) & $39(25.7)$ & $12(07.9)$ & $10(6.6)$ & $4(2.6)$ & $3(2.0)$ \\
\hline & PA 5 & 37 (24.3) & $26(17.10$ & $24(15.8)$ & $26(17.1)$ & $15(9.9)$ & $7(4.6)$ & $17(11.2)$ \\
\hline & PA 6 & $40(26.3)$ & 32 (21.1) & $27(17.8)$ & $29(19.1)$ & $10(6.6)$ & $8(5.3)$ & $6(3.9)$ \\
\hline & PA 7 & $65(42.8)$ & $40(26.3)$ & 24 (15.8) & 04 (02.6) & 7 (4.6) & 7 (4.6) & $5(3.3)$ \\
\hline & PA 8 & $69(45.4)$ & 35 (23.0) & 16 (10.5) & 18 (11.8) & $6(3.9)$ & $3(2.0)$ & $5(3.3)$ \\
\hline \multirow{2}{*}{\multicolumn{9}{|c|}{ Verbal Aggression }} \\
\hline & & & & & & & & \\
\hline & VA10 & $27(17.8)$ & 34 (22.4) & $15(9.9)$ & 28 (18.4) & $14(9.2)$ & $12(7.9)$ & $22(14.5)$ \\
\hline & VA 11 & 30 (19.7) & 35 (23.0) & 28 (18.4) & 21 (13.8) & $16(10.5)$ & 12 (7.9) & $10(6.6)$ \\
\hline & VA 12 & $31(20.4)$ & 18 (11.8) & 34 (22.4) & 28 (18.4) & 20 (13.2) & $10(6.6)$ & $11(7.2)$ \\
\hline & VA 13 & $36(23.7)$ & 29 (19.1) & $29(19.1)$ & $20(13.2)$ & 17 (11.2) & $9(5.9)$ & $12(7.9)$ \\
\hline & VA 14 & $50(32.9)$ & $28(18.4)$ & $25(16.4)$ & $23(15.1)$ & $15(9.9)$ & 7 (4.6) & $4(2.6)$ \\
\hline \multicolumn{9}{|l|}{ Anger } \\
\hline & AN15 & $38(25.0)$ & $24(15.8)$ & $24(15.8)$ & $22(14.5)$ & 19 (12.5) & $16(10.5)$ & $9(5.9)$ \\
\hline & AN 16 & 34 (22.4) & 28 (18.4) & 28 (18.4) & 24 (15.8) & 19 (12.5) & $11(7.2)$ & $8(5.3)$ \\
\hline & AN 17 & 44 (28.9) & 32 (21.1) & $27(17.8)$ & 20 (13.2) & $11(7.2)$ & $10(6.6)$ & $7(4.6)$ \\
\hline & AN 18 & 28 (18.4) & 34 (22.4) & 23 (15.1) & 29 (19.1) & 20 (13.2) & $8(5.3)$ & $9(5.9)$ \\
\hline & AN 19 & $39(25.7)$ & 30 (19.7) & $23(15.1)$ & $22(14.5)$ & 18 (11.8) & $15(9.9)$ & $5(3.3)$ \\
\hline & AN 20 & $41(27.0)$ & 22 (14.5) & 28 (18.4) & 23 (15.1) & $15(9.9)$ & 13 (8.6) & $8(5.3)$ \\
\hline \multirow{2}{*}{\multicolumn{9}{|c|}{ Hostility }} \\
\hline & & & & & & & & \\
\hline & HS22 & $49(32.2)$ & 34 (22.4) & $24(15.8)$ & 19 (12.5) & $11(7.2)$ & $5(3.3)$ & $10(6.6)$ \\
\hline & HS 23 & $41(27.0)$ & $36(23.7)$ & $21(13.8)$ & 24 (15.8) & $15(9.9)$ & 7 (4.6) & $8(5.3)$ \\
\hline & HS 24 & $40(26.3)$ & $37(24.3)$ & 32 (21.1) & $15(9.9)$ & $16(10.5)$ & $6(3.9)$ & $6(3.9)$ \\
\hline & HS 25 & $41(27.0)$ & 36 (23.7) & $26(17.1)$ & 19 (12.5) & $16(10.5)$ & $6(3.9)$ & $8(5.3)$ \\
\hline & HS 26 & $38(25.0)$ & $38(25.0)$ & $20(13.2)$ & 18 (11.8) & 17 (11.2) & $9(5.9)$ & $12(7.9)$ \\
\hline & HS 27 & 35 (23.0) & 19 (12.5) & $15(9.9)$ & $29(19.1)$ & $31(20.4)$ & $13(8.6)$ & $10(6.6)$ \\
\hline & HS 28 & $33(21.7)$ & 24 (15.8) & $29(19.1)$ & 19 (12.5) & 23 (15.1) & $12(7.9)$ & $12(7.9)$ \\
\hline & HS 29 & $20(13.2)$ & $11(7.2)$ & $14(9.2)$ & $20(13.2)$ & $26(17.1)$ & 33 (21.7) & 28 (18.4) \\
\hline
\end{tabular}




\section{DISCUSSION}

Harassment is one of the several blurring problems of patriarchic society because the male dominancy legitimatizes male liberty even the liberty to steal the freedom of the other. In such a society, the liberation used to be considered as violation of cultural rules and regulation. Thus, victims of such structural remained reserve and compliant.

In the study, researcher has dealt with the same issue. In defined cultural values, male dominancy is one of the preferred values which directly related to the suppression of females. This suppression makes them culturally vulnerable and economically dependent. However, in such society female also struggled to be economically independent or to support their family in case if they belong to lower class family but if they do so, conservatives considered it cultural heresy.

Considering it cultural heresy it follows stigmatization. Somehow, working women labeled with modern value oriented which is, in the cultural context, an appealing, loose character, unethical and aberrant women. Thus, a male in such culture perceive such women as sexual object. Working women for them is most easily available object for teasing and sexual offers even for professional male. In such culture driven collective mind of male sex, harassment is one of the most amusing activity of proud because it has associated with the infliction of cultural values by confliction of harassment.

Conclusively, the patriarchic collective mind demands female to be obedient while female strives for emancipation to prove themselves as equally acceptable first citizens which in return threat to culturally defined values of patriarchic structure. Therefore, the harassment is one of the patriarchic response to females' strives to get away from subjugation. Female adopts several strategies to cope with such agitating surrounding that affects their mental health, cause to increase stress and aggression same as harassment does.

\section{REFERENCES}

[1] Ali, S. R. O., Zakaria, Z., Said, N. S. M., \& Yusof, H. S. M. (2016). Sexual harassment among hotel employees in Malaysia: the risk factor and effect. The Social Sciences, 11(13), 3321-3325.

[2] Aloka, J. (2009). Prevalence and management of sexual harassment at the workplace: the case of Uganda Prison Service (Doctoral dissertation, Makerere University). (p.7)

[3] Blackstone, A., Houle, J., \& Uggen, C. (2014). "I didn't recognize it as a bad experience until I was much 
older": Age, experience, and workers' perceptions of sexual harassment. Sociological Spectrum, 34(4), 314-337.

[4] Baron, S., Bond, M. A., Cazeca, D., Daniel, S., Kalaja, A., Markkanen, P., \& Tsurikova, L. (2007). Expanding our understanding of the psychosocial work environment: a compendium of measures of discrimination, harassment and work-family issues. Department of Health and Human Services, Centers for Disease Control and Prevention, National Institute for Occupational Safety and Health.

[5] Bartky, S. L. (1990). Femininity and domination: Studies in the phenomenology of oppression. Psychology Press. p. 27

[6] Calogero, R. M. (2004). A test of objectification theory: The effect of the male gaze on appearance concerns in college women. Psychology of Women Quarterly, 28(1), 16-21.

[7] Chambers Jr, H. L. (2001). (Un) Welcome Conduct and the Sexually Hostile Environment. Ala. L. Rev., 53,733 .

[8] Einarsen, S., Hoel, H., Zapf, D., \& Cooper, C. L. (2011). The concept of bullying and harassment at work: The European tradition. Bullying and harassment in the workplace: Developments in theory, research, and practice, 2, 3-40.

[9] Fitzgerald, L. F., Gelfand, M. J., \& Drasgow, F. (1995). Measuring sexual harassment: Theoretical and psychometric advances. Basic and Applied Social Psychology, 17(4), 425-445.

[10] Gervais, S. J., Vescio, T. K., \& Allen, J. (2011). When what you see is what you get The consequences of the objectifying gaze for women and men. Psychology of Women Quarterly, 35(1), 5-17.

[11] Güney, S., Gohar, R., Akıncı, S. K., \& Akınc1, M. M. (2006). Attitudes toward women managers in Turkey and Pakistan. Journal of International Women's Studies, 8(1), 194-211.

[12] Gutek, B. A., \& Koss, M. P. (1993). Changed women and changed organizations: Consequences of and coping with sexual harassment. Journal of Vocational Behavior, 42(1), 28-48.

[13] Harrison, J., \& Kanoff, K. (2010). Perceptions of sexual harassment on the inside. Corrections Compendium, 35(1), 8-15.

[14] Hershcovis, M. S. (2006). The prediction and consequences of 
workplace aggression: A metaanalytic approach (Order No. NR18518).

[15] Joshi, J. H., \& Nachison, J. (1996). Sexual Harassment in the Workplace: How to Recognize It, how to Deal with it: a Guidelines Paper. CGIAR Secretariat, World Bank.

[16] Kamal, A., Hassan, S., \& Khalil, A. (2002). Sexual harassment at workplace: five women workers experiences. Pakistan Journal of Psychological Research, 17(1-2).

[17] Kaschak, E. (1992). Engendered lives: a new psychology of women's experience. New York, NY: Basic Books.

[18] Keashly, L., \& Harvey, S. (2006). Workplace emotional abuse. Handbook of workplace violence, 95-120.

[19] LeMoncheck, Linda, Loose Women, Lecherous Men:A Feminist Philosophy of Sex (Oxford Universitypress, 1997), ISBN 978-0-19-510556-8, p. 133

[20] Lucero, M.A., Allen, R. E. \& Middleton, L. K. (2006). Sexual harassers: Behaviors, motives, and change over time. Sex Roles, 55 (5-6), 331-343. doi:http://dx.doi.org/10.1007/s111 99-006-9087-y
[21] Naveed, A., \& Alwani, N. (2010). Sexual harassment at work place: are you safe?. Journal of Ayub Medical College, 22(3), 222.

[22] O'Reilly, S. (2008). In the grip of it. Personnel Today, 21-22.

[23] Owens, H., Rosner, R., \& Harmon, R. B. (1995). Obsessional harassment and erotomania in a criminal court population. Journal of Forensic Science, 40(2), 188-196.

[24] Schat, A.C.H., \& Kelloway, E.K. (2000). Effects of perceived control on the outcomes of workplace aggression and violence. Journal of Occupational Health Psychology, 5, 386-402.

[25] Vogt, D., Bruce, T. A., Street, A. E., \& Stafford, J. (2007). Attitudes toward women and tolerance for sexual harassment among reservists. Violence Against Women, 13(9), 879-900.

[26] Wear, D., \& Aultman, J. (2005). Sexual harassment in academic medicine: persistence, non-reporting, and institutional response. Medical education online, 10(1), 4377.

[27] Wesselmann, E. D., \& Kelly, J. R. (2010). Cat-calls and culpability: Investigating the frequency and functions of stranger harassment. Sex roles, 63(7-8), 451-462. 